\title{
Testing Flowering Perennial Plants in a Bermudagrass (Cynodon spp.) Lawn
}

\author{
Paige E. Boyle \\ Department of Plants, Soils, and Climate, Utah State University, 4820 Old \\ Main Hill, Logan, UT 84322
}

Michelle M. Wisdom and Michael D. Richardson

Department of Horticulture, University of Arkansas, 316 Plant Science Building, Fayetteville, AR 72701

Additional index words. pollinators, Prunella vulgaris, self-heal, strawberry clover, Trifolium fragiferum, Trifolium repens, white clover

\begin{abstract}
Most pollinating insects require a season-long succession of floral resources to fulfill life-cycle requirements. Incorporating forbs into turfgrass sites may create a season-long sequence of flowers to support foraging pollinators. However, persistence of forbs in warm-season turfgrasses such as bermudagrass (Cynodon spp.) may be affected by the competitive nature of the turfgrass and routine management practices such as mowing. A 2-year study was conducted to evaluate seven forbs (Bellis perennis L., Lotus corniculatus L., Prunella vulgaris L., Trifolium fragiferum L. 'Fresa', Trifolium repens $\mathbf{L}$. 'Durana' and 'Resolute', Trifolium subterraneum L.) for persistence and ability to produce floral resources for pollinating insects in a low maintenance bermudagrass lawn. Plugs of each species were incorporated into 'Riviera' bermudagrass in Apr. 2016. Vegetative cover, flower production, flowering period and pollinator foraging were assessed. Prunella vulgaris bloomed July through August and achieved $100 \%$ cover (0\% bermudagrass) by 2017. Trifolium repens achieved a more balanced competitive density with the bermudagrass and produced flowers from June through August in both years. Trifolium fragiferum persisted over two growing seasons but only bloomed in 2017. Bellis perennis, Lotus corniculatus and Trifolium subterraneum did not persist. Pollinators were observed foraging on all persistent, flowering forbs, including Trifolium repens, Prunella vulgaris, and Trifolium fragiferum. Trifolium repens and Prunella vulgaris produced the most flowers and attracted the most pollinators.
\end{abstract}

The plant-pollinator relationship is mutually beneficial, as plants supply nourishment in the form of pollen and nectar to the insect while the insect ensures reproduction and survival in plants (Ollerton et al., 2011). Human and animal populations also benefit from healthy plant-pollinator affiliations through the production of horticultural foods (fruits, vegetables, nuts, etc.), grains, and animal feed. Examples of biotic pollinators include bees, wasps, and ants (all members of Hymenoptera), butterflies and moths (Lepidoptera), flies (Diptera), beetles (Coleoptera), birds (Apodiformes), and some mammals (Potts et al., 2016). In a society that relies on agriculture to support healthy living standards, pollination services are critical to ensure the continued ability of the world to feed its population.

All bee species rely exclusively on pollen and nectar collected from flowers for their dietary requirements (Michener, 1974), and

Received for publication 2 June 2020. Accepted for publication 23 July 2020.

Published online 26 August 2020.

P.E.B. is the corresponding author. E-mail: paige. boyle23@gmail.com.

This is an open access article distributed under the CC BY-NC-ND license (https://creativecommons. org/licenses/by-nc-nd/4.0/). nators either because they produce insufficient pollen or nectar or because those resources are not easily accessible by foraging insects (U.S. Forest Service, n.d.). Maintaining diverse, season-long floral resources is also essential to support a diverse pollinator community (Williams et al., 2015). Guidelines suggest the inclusion of at least three flowering plants at any given time during spring, summer, and/or fall (Vaughn and Skinner, 2015). Clumping single species together and placing foraging habitat adjacent to nesting sites will also attract pollinating insects (Spivak et al., 2011).

Pollinator populations have dropped in recent decades due to habitat fragmentation and loss (Kremen et al., 2007; Murray et al., 2009), the large-scale planting of monocultures and expansion of pesticide use (Goulson et al., 2015), poor nutrition (Alaux et al., 2010), the introduction of exotic pests and diseases (Goulson, et al., 2015), colony collapse disorder in honeybees (Van Engelsdorp et al., 2009), and climate change (Biesmeijer et al., 2006; Goulson et al., 2008). Each might be considered a standalone threat to pollinator health; combined, they represent a massive hurdle to pollinator survival, which can have significant societal consequences, including an increased vulnerability of global agricultural output (Gallai et al., 2009).

Significant expanses of managed turfgrasses, such as roadsides, cemeteries, and lawns, represent areas of land that might also be designed and managed to feed pollinating insects (Hopwood, 2008; Ries et al., 2001). Historically, seed mixtures for lawns included clover and other legumes to enhance nitrogen availability for the turfgrass (Tyson, 1941). However, with advances in chemical herbicides and fertilizers in the mid-20th century, a more "weed-free" lawn became desirable, and many forbs have been eliminated from turfgrass ecosystems, consequently eliminating floral resources for pollinators (Larson et al., 2014).

Lawns that incorporate both forbs and turf are meant to maintain the benefits of turfnamely resilience to recreation and trafficwhile potentially reducing inputs from irrigation, fertilizers, pesticides, and mowing (Cook, 2005); incorporating forbs in turfgrass sites could also create additional floral resources for pollinators. Such plants must be able to compete with turfgrasses by flowering and persisting under mowing pressure and variable fertility and irrigation. Bermudagrass (Cynodon spp.), a warm-season turfgrass, is one of the most commonly used lawn and utility turfs in tropical and subtropic climates. Bermudagrass grows rapidly by rhizomes and stolons and has a dense, spreading growth habit that is competitive against weeds and other plants.

Much of the clover and grass mixture research has been conducted in pasture settings with more robust 'Ladino' clovers; however, pasture stands have different management practices than turfgrass. Recent studies have investigated establishment of microclover and 'Dutch' white clover (Trifolium 
repens) into bermudagrass (McCurdy et al., 2013a) as a nitrogen source for the turf. Further research is warranted to evaluate different white clover varieties in turf settings. The white clover cultivars 'Durana' and 'Resolute' used in the present study were specifically bred for grazing tolerance (Bouton et al., 2005) and are considered intermediate cultivars between common white clovers and dwarf microclovers. As such, we assumed they would tolerate mowing as well. Additionally, research investigating the persistence of clovers and other forbs in bermudagrass and pollinator preference for these flowers is limited. White clover in bermudagrass lawns has been identified as an important source of pollinator forage (Larson et al., 2014), and Wisdom et al. (2019) identified several bulbs, primarily Crocus and Muscari spp., that persist in bermudagrass lawns and provide early spring pollinator forage.

This study sought to identify flowering perennial plants that would produce floral resources for pollinating insects. A significant consideration was the selection of plants that could coexist and persist under the growth and maintenance of bermudagrass turf. Although successful seed establishment of white clover into a bermudagrass lawn has been previously reported (McCurdy et al., 2013a), it was unclear whether the other species of interest could be direct-seeded into a competitive bermudagrass sward. Birdsfoot trefoil, for example, has had limited success establishing when sown directly into grass (e.g., Cuomo et al., 2001). As such, all entries were started from seed in the greenhouse and transplanted into the field. Our initial goal in the present study was to identify plants that could persist in the turf, and it was assumed that follow-up studies would be needed to develop effective planting methods for species of interest. It was our goal to identify and test forbs to create a useful plant list for home, land, or business owners who are interested in incorporating pollinator-friendly flowering perennials into their landscapes; therefore, the objectives of this study were to 1) identify flowering plants that persist in bermudagrass, 2) identify the flowering periods of these forbs, and 3) determine pollinator preference for these flowering perennials.

\section{Materials and Methods}

A field study was established at the University of Arkansas Agricultural Research and Experiment Center located in Fayetteville, AR (36:05:46.8 N, 94:10:28.5 W NAD83, 394 m NAVD88). The soil was a Captina silt loam (fine-silty, siliceous, active, mesic Typic Fragidults) with an average $\mathrm{pH}$ of 6.2. The study area was a full-sun, mature turf site established in 2005 to 'Riviera' common bermudagrass (Cynodon dactylon L. Pers).

Seven forbs commonly found in Arkansas lawns (Table 1) were selected based on reported mature height and bloom period (Missouri Botanical Garden, n.d.; U.S. Department of Agriculture, 2019). All entries were started from seed in the greenhouse and transplanted into the field. Seeds were sown into 50-cell plug trays (Greenhouse Megastore, Danville, IL) containing potting mix (Miracle Grow Moisture Control Potting Mix, Scotts Miracle-Gro Company, Marysville, $\mathrm{OH}$ ) on 15 Feb. 2016 at the University of Arkansas Rosen Alternative Pest Control Center in Fayetteville. Clover, birdsfoot trefoil, and self-heal were seeded one seed per cell; due to the small seed size and difficulty in separating seed, English daisy was seeded at three seeds per cell. When the first true leaves were developed, English daisy seedlings were thinned to a single plant, and plugs of all species were transplanted into $10-\mathrm{cm}$ diameter pots (Greenhouse Megastore). Temperature in the greenhouse was maintained at a day/night temperature of $30 / 24{ }^{\circ} \mathrm{C}$ until 1 Apr., when temperature was lowered to $27 /$ $21{ }^{\circ} \mathrm{C}$; temperatures were lowered again to 24/18 ${ }^{\circ} \mathrm{C}$ on 4 Apr. On 11 Apr. 2016, plugs were transferred to an unheated greenhouse and were transplanted into the field on 14 Apr. 2016.

The experimental design was a singlefactor (forb) randomized complete block with four replicates. Although the total plot area for each treatment was $3.3 \mathrm{~m}^{2}(1.8 \times$ $1.8 \mathrm{~m}$ ), nine plugs were planted in a $0.8 \mathrm{~m}^{2}$ area $(0.9 \times 0.9 \mathrm{~m})$ at $30 \mathrm{~cm}$ spacings in the center of each plot. Planting holes were made using a 11.4-cm-diameter turfgrass cup cutter to a depth of $8.9 \mathrm{~cm}$; plugs were placed into the holes and covered with loose soil.

Mowing was initiated in the third week of May 2016 and the second week of May 2017 after bermudagrass broke dormancy. Plots were mowed on a 14-day schedule to a height of $7.5 \mathrm{~cm}$ during the growing season to simulate a low-maintenance lawn. The turf received a single application of nitrogen fertilizer in July of each year at a rate of 7.5 $\mathrm{g} \cdot \mathrm{m}^{-2} \mathrm{~N}$ (46-0-0, Thrive Branded Urea, Mears Fertilizer, Inc., El Dorado, KS). Soil test analyses indicated that other soil nutrients were sufficient for a bermudagrass lawn in this region. To protect the forbs, chemical weed control was not used; instead, plots and alleyways were hand-weeded when weeds encroached on study entries. Supplemental irrigation was applied as needed to adequately wet the soil and aid in forb establishment but was withheld during the remainder of the study.

Data collection focused on establishment, performance, and persistence of forbs over the 2 -year period. Each treatment was evaluated for average percent vegetative cover, number of flowers, and pollinator activity on flowers. Vegetative cover was measured twice monthly by placing a $1 \times 1 \mathrm{~m}$ grid with intersects spaced at $10-\mathrm{cm}$ intervals over the center of each plot and counting the number of intersects where the forb was present. Flower counts were taken two or three times monthly by randomly tossing a $30 \times 30$-cm wooden template into each plot two times and counting flowers within the template. Pollinator activity counts were measured at least two times per week when pollinating insects were observed to be active within the study site. During a 1-minute visual inspection, pollinators that landed on flowers and foraged were counted, whereas pollinators that landed but did not forage were not counted. Pollinators were not collected but were broadly categorized in the field as honeybees, bumble bees (Bombus spp.), other native bees (Hymenoptera), butterflies (Lepidoptera), or "other," which included ants and wasps (also Hymenoptera), beetles (Coleoptera), flies, and hoverflies (Diptera), to provide a qualitative assessment of pollinator activity.

Vegetative cover, flower counts, and pollinator visits were averaged by month and analyzed in a repeated-measures analysis of variance model in PROC MIXED (SAS v. 9.4, SAS Institute, Inc., Cary, NC) where month was included as the time in the analysis. When main effects and interactions were significant $(P<0.05)$, means were separated according to Fisher's protected least significant difference test.

\section{Results and Discussion}

For vegetative cover, flower counts, and pollinator visits, the entry $\times$ month interaction was statistically significant (data not shown).

Vegetative cover. English daisy attained up to $54 \%$ vegetative cover in 2016 (Fig. 1), but only a single plant emerged in 2017 (Fig. 1). 'Durana' and 'Resolute' white clover cover increased throughout the 2016 season (Fig. 1). 'Durana' white clover (Fig. 2A) had significantly greater vegetative cover than all other entries at the end of 2016 , with $84 \%$ cover (Fig. 1). In 2017, vegetative cover of both 'Durana' and 'Resolute' white clovers declined throughout the season (Fig. 1). White clover vegetative cover was not significantly different between cultivars in Apr. 2017, but by the end of the 2017 season, 'Durana' white clover had significantly more vegetative cover than 'Resolute' white clover, strawberry clover, birdsfoot trefoil, and English daisy (Fig. 1).

Self-heal (Fig. 2B) reached 67\% vegetative cover in bermudagrass at the end of the 2016 growing season and maintained significantly more cover than all other entries June through Aug. 2017 (Fig. 1). Strawberry clover attained $35 \%$ cover at the end of 2016 and maintained significantly less vegetative cover than the white clovers and self-heal, but significantly more cover than birdsfoot trefoil and English daisy in Aug. and Sept. 2016 (Fig. 1). Strawberry clover maintained 30\% vegetative cover, significantly less than both white clovers and self-heal, but greater than birdsfoot trefoil and English daisy between Apr. and July 2017; however, vegetative cover was $<10 \%$ by Aug. 2017 (Fig. 1). Birdsfoot trefoil (Fig. 2B) reached 21\% vegetative cover in June-July 2016 but declined in cover beginning in Aug. 2016 (Fig. 1) and reached $<5 \%$ by the end of the first season; birdsfoot trefoil struggled to persist throughout 2017 (Fig. 1). Although subterranean clover was present through June 2016, it was undetectable by July 2016 and did not emerge in 2017 (data not shown). 
Table 1. Species, height, and bloom time reported in online databases, and seed source of flowering plants established from plugs into a bermudagrass lawn in Fayetteville, AR.

\begin{tabular}{|c|c|c|c|c|}
\hline Species & Common name & $\mathrm{Ht}(\mathrm{cm})$ & Bloom time & Seed source \\
\hline Bellis perennis & English daisy & $7.6-15.2$ & May-July & Monticello (Charlottesville, VA) \\
\hline Lotus corniculatus & Birdsfoot trefoil & $7.6-15.2$ & May-Oct. & Eden Brothers (Asheville, NC) \\
\hline Prunella vulgaris & Self-heal & $10.6-50.8$ & Apr.-Sept. & Mountain Rose Herbs (Eugene, OR), Strictly Medicinal (Williams, OR) \\
\hline Trifolium fragiferum 'Fresa' & Strawberry clover & $20.3-35.6$ & May-June & Outside Pride (Independence, OR) \\
\hline Trifolium repens 'Durana' & White clover & $7.6-15.2$ & May-June & University of Georgia (Athens, GA) \\
\hline Trifolium repens 'Resolute' & White clover & $7.6-15.2$ & May-June & University of Georgia (Athens, GA) \\
\hline Trifolium subterraneum & Subterranean clover & $<15.2$ & Late spring & Outside Pride (Independence, OR) \\
\hline
\end{tabular}

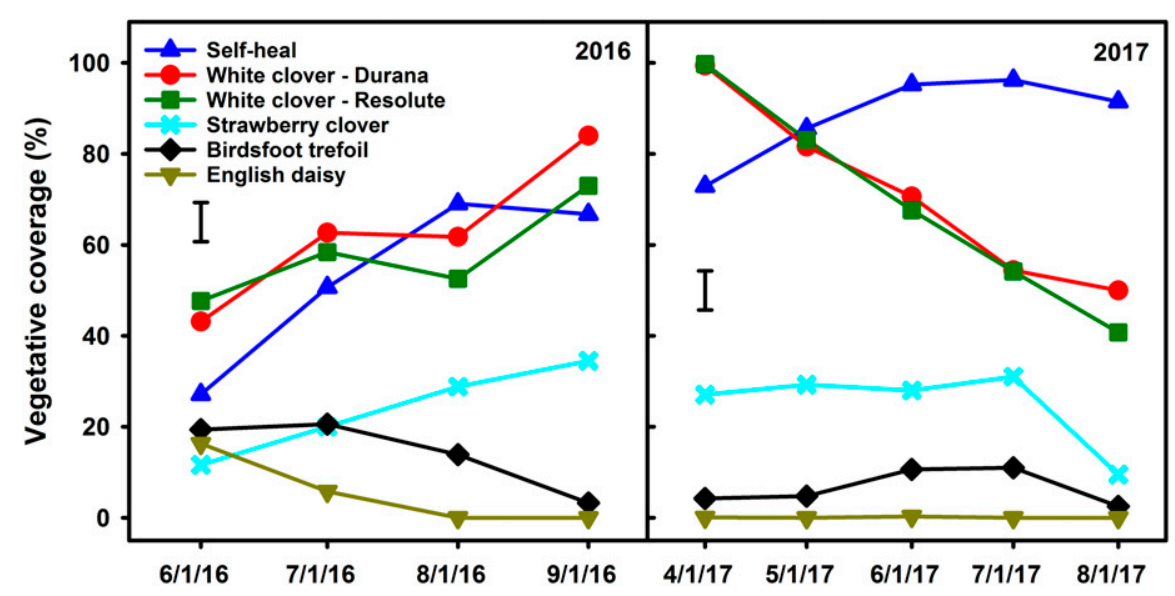

Fig. 1. Vegetative cover of six herbaceous perennials in bermudagrass over two growing seasons in Fayetteville, AR. Error bars represent the least significant difference $(P=0.05)$ for comparing means.

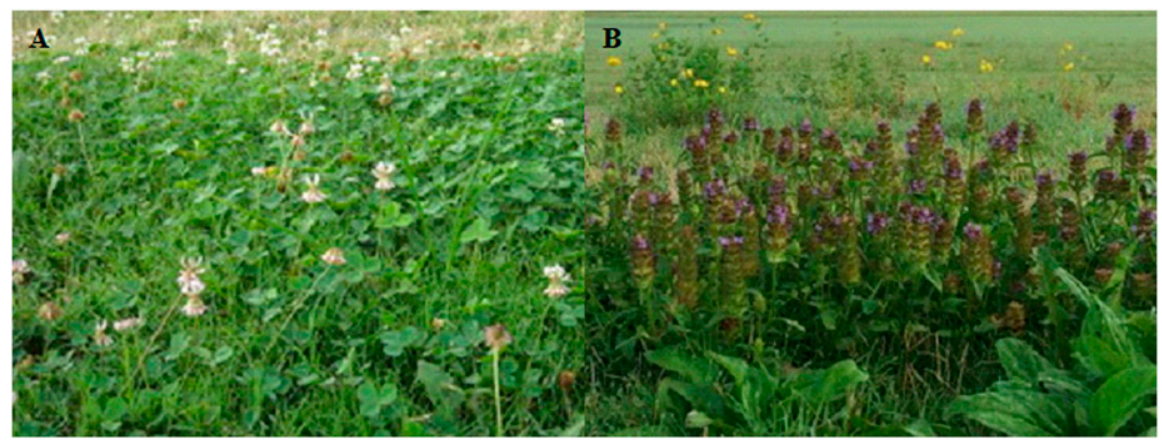

Fig. 2. Bermudagrass with (A) 'Durana' white clover, 9 Aug. 2016. (B, foreground) Self-heal and (B, background) birdsfoot trefoil, 17 Aug. 2016.

Strawberry clover and 'Resolute' and 'Durana' white clovers persisted in a mixed stand with the bermudagrass over a 2-year period. Self-heal overtook the bermudagrass and may not be a suitable companion planting option with bermudagrass; more research may explore different planting densities, management techniques, or companion grass species for self-heal flowering lawns.

Flowering period. English daisy was flowering when transplanted into the study site in Apr. 2016, but only one flower was observed in 2017. Self-heal initiated flowering in July 2016 and June 2017 and had significantly more flowers than other entries in Aug. and Sept. 2016 and July and Aug. 2017 (Fig. 3). Both white clovers initiated flowering in Apr. 2016 and 2017 and produced maximum flowers from June through July of both years, with 'Resolute' producing significantly more flowers in June and July
2016 and May and June 2017 than other entries (Fig. 3). Although strawberry clover did not flower in 2016, flowering was initiated in June 2017, and maximum flower counts were observed from June through July 2017; flower counts were significantly greater than self-heal (June 2017), birdsfot trefoil (June-Aug. 2017), and English daisy (JuneAug. 2017) during this time (Fig. 3). Birdsfoot trefoil began flowering in June 2016 and 2017, with greatest flower counts observed in early July of both years (Fig. 3). Subterranean clover did not flower during the course of this study (data not shown).

'Resolute' and 'Durana' white clovers produced spring and summer (June-July) flowers, whereas self-heal produced flowers in late summer and fall (July-September). Strawberry clover also produced late-season flowers (June-August), although these were less abundant than the white clovers and fall- flowering self-heal. More research is needed to investigate persistence of mixed stands of bermudagrass and multiple forbs to provide a succession of yearlong bloom in a flowering lawn.

Pollinator visits. Both cultivars of white clover received significantly more pollinator visits than other forbs in June and July 2016 and June through mid-July 2017, although 'Resolute' received significantly more visits than 'Durana' during 2016 (Fig. 4). Significantly more pollinators were observed on self-heal in Aug. 2016 and mid-July 2017 (Fig. 4). Although English daisy flowers were present in June 2016 (Fig. 3), significant pollinator activity was not observed (Fig. 4); due to lack of persistence (Fig. 1), pollinator activity was not observed on English daisy in 2017 (Fig. 4). Because strawberry clover did not flower in 2016 (Fig. 3), no pollinators were observed foraging on this entry (Fig. 4). In 2017, strawberry clover flowered (Fig. 3) but did not attract a significant number of pollinators (Fig. 4). Birdsfoot trefoil did not attract a significant number of pollinators during the course of this study (Fig. 4). Subterranean clover did not produce flowers and therefore did not attract pollinating insects during the course of this study (data not shown). A variety of pollinators was observed on the herbaceous perennials studied in this trial, including honeybees, bumble bees, and other native bees, butterflies, ants, wasps, and flies (Table 2). The white clover entries harbored the greatest number and diversity of pollinators (Table 2).

Clovers (Trifolium spp.) are generally known to be adapted to a wide range of climatic and soil conditions (Olsen and Smith, 2016), and clover seed was historically included in turfgrass mixtures, primarily to add nitrogen to the turfgrass ecosystem (Tyson, 1941). White clover is a low-growing, perennial legume (Olsen and Smith, 2016) that can flower and produce seed at mowing heights as low as $6 \mathrm{~mm}$ (Watschke et al., 1995). Today, clover inclusion within maintained turfgrass is a proposed means of increasing turfgrass sustainability by reducing fertilizer inputs and enhancing biodiversity (McCurdy et al., 2013b). Scientists have conducted numerous studies incorporating white clover into lawns to supplement the nitrogen requirements of grass swards and potentially increase pollinator habitat (Larson et al., 2014; McCurdy et al., 2014; Sincik and Acikgoz, 2007). In the present trial, it was observed that the white clover entries enhanced the dark green color of the associated 


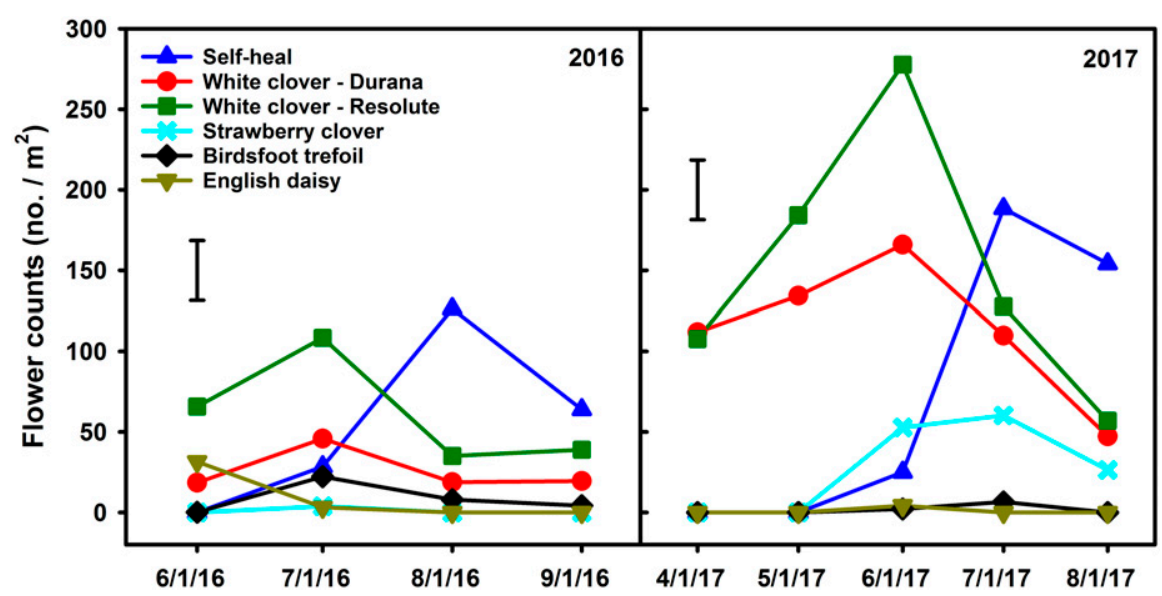

Fig. 3. Flower counts of six herbaceous perennials in bermudagrass over two growing seasons in Fayetteville, AR. Error bars represent the least significant difference $(P=0.05)$ for comparing means.

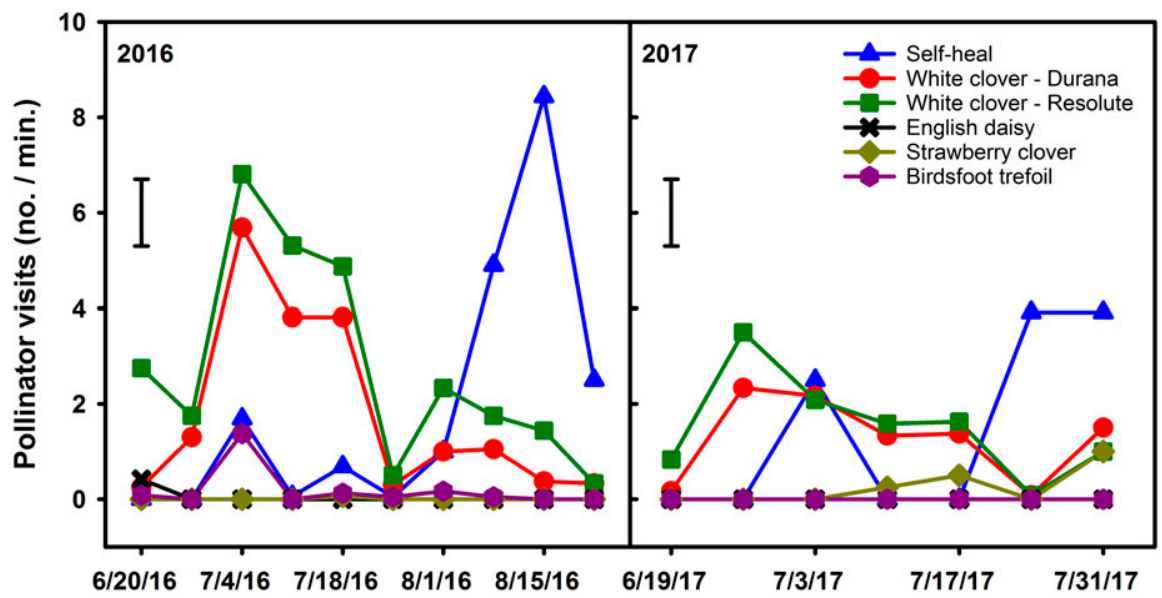

Fig. 4. Pollinator visits on six herbaceous perennials in bermudagrass over two growing seasons in Fayetteville, AR. Error bars represent the least significant difference $(P=0.05)$ for comparing means.

Table 2. Pollinator diversity on herbaceous perennials in bermudagrass in Fayetteville, AR, June-Aug. 2016 and 2017.

\begin{tabular}{lccccc}
\hline & Honey bee & Bumble bee & Native bee & Butterfly & Other $^{2}$ \\
\cline { 2 - 6 } Species & \multicolumn{5}{c}{$\operatorname{Avg}(\mathrm{n}=65)$ pollinator visits } \\
\hline English daisy & 0 & 0 & 4 & 0 & 0 \\
Birdsfoot trefoil & 4 & 0 & 0 & 1 & 5 \\
Self-heal & 0 & 4 & 0 & 2 & 0 \\
Strawberry clover 'Fresa' & 10 & 0 & 0 & 0 & 0 \\
White clover 'Durana' & 14 & 14 & 0 & 4 & 2 \\
White clover 'Resolute' & 19 & 1 & 12 & 3 \\
\hline
\end{tabular}

${ }^{\mathrm{z}}$ Other includes ant, wasp, fly, and hummingbird.

bermudagrass, presumably by the nitrogen fixation of the symbiotic rhizobium strains associated with white clover.

A study conducted at the University of Minnesota determined that self-heal and white clover can persist in hard fescue [Festuca trachyphylla (Hack.) Krajina] and supply forage for pollinators in home lawns or low maintenance turf areas such as roadsides or cemeteries (Lane et al., 2019b). The current study confirms that white clover may also be a potential source of spring and summer pollinator forage in bermudagrass lawns. Self-heal also flowered and provided summer pollinator forage; however, self-heal exhibited $100 \%$ cover and may not be suitable for a forb and turf mixture with bermu2019b), although English daisy did not persist in this study.

Although this study demonstrates that some forbs can persist in equilibrium with bermudagrass, additional studies are needed to evaluate other flowering perennials that might support pollinators and beneficial insects, as well as other turfgrass species that may be suitable for pollinator-friendly forbs. Some common lawn weeds, such as purple deadnettle (Lamium purpureum L.) and henbit (Lamium amplexicaule L.), are also used by pollinators in early spring (Brown, 2016; Steinkraus, 2010), and both support honeybees and many native bee species. Although these plants are most often considered weedy species, each is a potential source for pollinator nutrition and might be adapted or transitioned into lawns, roadsides, cemeteries, parks, and/or golf course out-of-play areas to provide pollinator nutrition and habitat. Zoysiagrass (Zoysia japonica Steud.) and buffalograss [Bouteloua dactyloides (Nutt.) Columbus] have successfully demonstrated ability to support flowering bulbs (Richardson et al., 2015; Wisdom et al., 2019), but other warm-season turfgrass species such as Eremochloa Buese and Stenotaphrum Trin. species might also be evaluated for ability to host forbs for pollinator forage. Cool-season grasses, such as Poa L., Festuca L., or Lolium L. spp., occupy many temperate climates, and several coolseason lawn species have successfully supported flowering forbs (Cook, 2005). In lawn settings, Kentucky bluegrass (Poa pratensis L.) can support Kura clover (Trifolium ambiguum M. Bieb.), and hard fescue can support Kura clover, white clover, self-heal, creeping thyme, and ground plum (Astragalus crassicarpus Nutt.) (Lane et al., 2019a, 2019b).

English daisy, birdsfoot trefoil, and subterranean clover did not persist and are not recommended for companion planting for flowering lawns in bermudagrass. Self-heal does provide pollinator forage, but bermudagrass coplanted with self-heal was thin and weak; because of this, self-heal is not a viable option if healthy bermudagrass/forb mixtures are desired. White clovers provided spring and summer flowers, attracted pollinators, and are recommended for companion planting with bermudagrass. Strawberry clover flowered in the second year, maintained significantly less cover than the white clovers, and may be used instead of white clover if more bermudagrass cover is desired; however, strawberry clover did not attract pollinators during the course of this study.

Turfgrass managers and homeowners might be hesitant to add clovers or other forbs to turf because forbs can alter the aesthetics, become invasive, and limit the ability to apply pesticides to control undesirable broadleaf weeds. An additional concern is the presence of bees in home lawns or other turf settings where children, pets, and adults with bee allergies may recreate. Discretion should be used when deciding where pollinator habitat is installed and how these areas are managed.

\section{Literature Cited}

Alaux, C., F. Ducloz, D. Crauser, and Y. Le Conte. 2010. Diet effects on honey bee immunocompetence. Biol. Lett. 6:562-656.

Biesmeijer, J.C., M. Edwards, R. Kleukers, W.E. Kunin, R. Ohlemuller, T. Peeters, S.G. Potts, M. 
Reemer, S.P.M. Roberts, A.P. Shaffers, J. Settele, and C.D. Thomas. 2006. Parallel declines in pollinators and insect-pollinated plants in Britain and the Netherlands. Science 313:351-354.

Bouton, J.H., D.R. Woodfield, J.R. Caradus, and D.T. Wood. 2005. Registration of 'Durana' white clover. Crop Sci. 45:797.

Brodschneider, R. and K. Crailsheim. 2010. Nutrition and health in honey bees. Apidologie 41:278-294.

Brown, D. 2016. Purple deadnettle and henbit; Two common garden spring weeds. Mich. State Univ. Ext. Pub. <http://msue.anr.msu.edu/news/purple_ deadnettle_and_henbit_two_common_garden_ spring_weeds $>$.

Cook, T. 2005. Low maintenance turf? 23 Apr. 2020. <https://agsci.oregonstate.edu/beaverturf/ low-maintenance-turf $>$.

Cuomo, G.J., D.G. Johnson, and W.A. Head, Jr. 2001. Interseeding kura clover and birdsfoot trefoil into existing cool-season grass pastures. Agron. J. 93:458-462.

Cussans, J., D. Goulson, R. Sanderson, L. Goffe, B. Darvill, and J.L. Osborne. 2010. Two beepollinated plant species show higher seed production when grown in gardens compared to arable farmland. PLoS One 5:E11753.

Gallai, N., J.M. Salles, J. Settele, and B.E. Vaissière. 2009. Economic valuation of the vulnerability of world agriculture confronted with pollinator decline. Ecol. Econ. 68:810-821.

Goulson, D., G.C. Lye, and B. Darvill. 2008. Decline and conservation of bumble bees. Annu. Rev. Entomol. 53:191-208.

Goulson, D., E. Nicholls, C. Botias, and E.L. Rotheray. 2015. Bee declines driven by combined stress from parasites, pesticides, and lack of flowers. Science 347(6229):1255957.

Hopwood, J.L. 2008. The contribution of roadside grassland restorations to native bee conservation. Biol. Conserv. 141:2632-2640.

Kremen, C., N.M. Williams, M.A. Aizen, B. GemmillHerren, G. LeBuhn, R. Minckley, L. Packer, S.G. Potts, T. Roulston, I. Steffan-Dewenter, D.P. Vázquez, R. Winfree, L. Adams, E.E. Crone, S.S. Greenleaf, T.H. Keitt, A.M. Klein, J. Regetz, and T.H. Ricketts. 2007. Pollination and other ecosystem services produced by mobile organisms: A conceptual framework for the effects of land-use change. Ecol. Lett. 10:299-314.

Lane, I., E. Watkins, and M. Spivak. 2019a. Turfgrass species affect the establishment and bloom of Kura clover (Trifolium ambiguum) in lawns. HortScience 54:824-828.

Lane, I.G., J. Wolfin, E. Watkins, and M. Spivak. 2019b. Testing the establishment of eight forbs in mowed lawns of hard fescue (Festuca brevipila) for use in pollinator conservation. HortScience 54:2150-2155.

Larson, J.L., A.J. Kesheimer, and D.A. Potter. 2014. Pollinator assemblages on dandelion and white clover in urban and suburban lawns. J. Insect Conserv. 18:863-873.

McGregor, S.E. 1976. Insect pollination of cultivated crop plants, USDA Handbook 496 U.S. Department of Agriculture, Agricultural Research Service, Washington, DC.

McCurdy, J.D., J.S. McElroy, and E.A. Guertal. 2013a. White clover (Trifolium repens) establishment within dormant bermudagrass turf: Cultural considerations, establishment timing, seeding rate, and cool-season companion grass species. HortScience 48:1556-1561.

McCurdy, J.D., J.S. McElroy, E.A. Guertal, and C.W. Wood. 2013b. Dynamics of white clover decomposition in a southeastern bermudagrass lawn. Agron. J. 105:1277-1282.

McCurdy, J.D., J.S. McElroy, E.A. Guertal, and C.W. Wood. 2014. White clover inclusion within a bermudagrass lawn: Effects of supplemental nitrogen on botanical composition and nitrogen cycling. Crop Sci. 54:1796-1803.

Michener, C.D. 1974. The social behavior of the bees: A comparative study, p. 404. 2nd ed. Harvard Univ. Press, Cambridge, MA.

Missouri Botanical Garden. n.d. Plant finder. $<$ https://www.missouribotanicalgarden.org/ plantfinder/plantfindersearch.aspx $>$.

Murray, T.E., M. Kuhlmann, and S. Potts. 2009. Conservation ecology of bees: Populations, species and communities. Apidologie 40:211-236.

Ollerton, J., S. Tarrant, and R. Winfree. 2011. How many flowering plants are pollinated by animals? Oikos 120:321-326.

Olsen, G.L. and S.R. Smith. 2016. 2016 red and white clover grazing tolerance report. Univ. Kent. Agr. Expt. Sta. PR-716.

Potts, S.G., V. Imperatriz-Fonseca, H.T. Ngo, M.A. Aizen, J.C. Biesmeijer, T.D. Breeze, L.V. Dicks, L.A. Garibaldi, R. Hill, J. Settele, and A.J. Vanbergen. 2016. Safeguarding pollinators and their values to human well-being. Nature 540:220-229.

Richardson, M.D., J. McCalla, T. Buxton, and F. Lulli. 2015. Incorporating early spring bulbs into dormant warm-season turfgrasses. HortTechnology 25:228-232.

Ritchie, A.D., R. Ruppel, and S. Jha. 2016. Generalist behavior describes pollen foraging for perceived oligolectic and polylectic bees. Environ. Entomol. 45:909-919.

Ries, L., D.M. Debinski, and M.L. Wieland. 2001. Conservation value of roadside prairie restora- tion to butterfly communities. Conserv. Biol. 15:401-411.

Robertson, C. 1925. Heterotrophic bees. Ecology $6: 412-436$.

Sincik, M. and E. Acikgoz. 2007. Effects of white clover inclusion on turf characteristics, nitrogen fixation, and nitrogen transfer from white clover to grass species in turf mixtures. Commun. Soil Sci. Plant Anal. 38:1861-1877.

Spivak, M., E. Mader, M. Vaughan, and N.H. Euliss, Jr. 2011. The plight of the bees. Environ. Sci. Technol. 45:34-38.

Steinkraus, D. 2010. Early spring flowers in northwest Arkansas: The excellent, the good, and the poor. Amer. Bee J. 150:351-354.

Tyson, J. 1941. Growing beautiful lawns. Mich. Agr. Expt. Sta. Res. Bul. 224.

U.S. Department of Agriculture. 2019. Plants Database. <https://plants.sc.egov.usda.gov/ java/>.

U.S. Forest Service. n.d. Bee pollination. 27 May 2020. <https://www.fs.fed.us/wildflowers/pollinators/animals/bees.shtml $>$.

Vaughn, M. and M. Skinner. 2015. Using farm bill programs for pollinator conservation. USDA Natural Resources Cons. Serv. National Plant Data Ctr. Biol. Tech. Note No. 78. 2nd ed. 28 Feb. 2018. <http://www.xerces.org/wp-content/ uploads/2008/11/using_farm_bill_programs_ xerces_society.pdf $>$.

Van Engelsdorp, D., J.D. Evans, C. Saegerman, C. Mullin, E. Haubruge, B.K. Nguyen, M. Frazier, J. Frazier, D. Cox-Foster, Y. Chen, R. Underwood, D.R. Tarpy, and J.S. Pettis. 2009. Colony collapse disorder: A descriptive study. Public Library of Science 4:1-17.

Wackers, F.L. and P.C.J. van Rijn. 2012. Pick and mix: Selecting flowering plants to meet the requirements of target biological control insects, p. 139-165. In: G.M. Gurr, S.D. Wratten, W.E. Snyder, and D.M.Y. Read (eds.). Biodiversity and insect pests: Key issues for sustainable management. Wiley, Chichester, England.

Watschke, T.L., P.H. Dernoeden, and D.J. Shetlar. 1995. Managing turfgrass pests. Lewis Publ., Boca Raton, FL.

Williams, N.M., K.L. Ward, N. Pope, R. Isaacs, J. Wilson, and E.A. May. 2015. Native wildflower plantings support wild bee abundance and diversity in agricultural landscapes across the United States. Ecol. Appl. 25:2119-2131.

Wisdom, M.M., M.D. Richardson, D.E. Karcher, D.C. Steinkraus, and G.V. McDonald. 2019. Flowering persistence and pollinator attraction of early-spring bulbs in warm-season lawns. HortScience 54:1853-1859. 